\title{
ANALISIS SISTEM KESEHATAN DAN KESELAMATAN KERJA DENGAN METODE ECFA DI. PT XYZ
}

\author{
Muhammad Nur ${ }^{*}$ \\ ${ }^{1}$ Jurusan Teknik Industri, Fakultas Sains dan Teknologi, Universitas Islam Negeri Sultan Syarif Kasim Riau, Pekanbaru- \\ Indonesia \\ ${ }^{*}$ Corresponding Author: ${ }^{1}$ muhammad.nur@uin-suska.ac.id
}

\begin{abstract}
Abstrak - Kecelakaan kerja panen tandan buah sawit di PT. XYZ selau terjadi kasus kecelakaan kerja yang menyebabkan kerugian pada PT. XYZ. Penelitian ini dilakukan untuk mengetahui penyebab serta usulan Kesehatan dan keselamatan kerja bagi karyawan bagian pemanen buah kelapa sawit di PT. XYZ. Metode yang digunakan dalam penelitian ini adalah metode Even and Causal Factor Analysis (ECFA). Berdasarkan hasil penelitian yang dilakukan diketahui bahwa penyebab kecelakaan dikarenakan tidak adanya SOP, tidak memakai APD, kurang pengawasan dari pimpinan, dan tidak adanya program kesehatan dan keselamatan kerja. Usulan perbaikan berupa membuat SOP kerja yang benar dan aman, mewajibkan penggunaan APD, peningkatan kesadaran dan pengetahuan karyawan, merencanakan pengadaan APD, pengawasan karyawan, dan membuat program kesehatan dan keselamatan kerja.
\end{abstract}

Kata Kunci: Kelapa Sawit, Kesehatan, keselamatan, Metode ECFA

\section{Pendahuluan}

PT. XYZ merupakan salah satu perusahaan yang bergerak dibidang pengolahan kelapa sawit menjadi Crude Palm Oil (CPO) dan Karnel Palm (KP), dalam memenuhi kebutuhan bahan baku tandan buah sawit (TBS) diperoleh dari perkebunan milik sendiri yang mencapai luas 4357,91 Ha dengan ouput 520 Ton/Hari. Tidak dapat dipungkiri perusahan sebesar ini akan memberikan dampak penyerapan tenaga kerja pemanen TBS yang besar pula. Seiring dengan itu dalam menjalankan pekerjaannya, karyawan pemenen TBS sangat beresiko tinggi mengalami kecelakaan kerja, hal ini diketahaui dari pengamatan di lapangan bahwa tidak adanya standar metode kerja yang baku, benar dan aman, antara satu karyawan dengan karyawan lainnya memiliki cara pemanenan TBS yang berbeda-beda. Kesalahan metode kerja ini dapat dilihat pada saat karyawan melakukan pemotongan pelepah sawit maupun buahnya secara bersamaan yang mengakibatkan jatuhnya pelepah dan buah menjadi tidak stabil dan tidak terkendali. Contoh lain dari metode kerja yang tidak benar yaitu mengegrek pelepah atau buah sawit secara terbalik, mata pisau egrek menghadap keatas dan memotong pelepah atau buah sawit dari bawah, hal ini akan menyebabkan pelepah atau buah sawit jatuh mengikuti alur sepanjang tangkai eggek dan menimpa karyawan. Dengan jatuhnya pelepah dan buah sawit yang tidak dapat diprediksi atau buah jatuh mengikuti alur tangkai eggek akan membuat karyawan tidak dapat menghindar ketika pelepah atau buah jatuh mengarah kepada karyawan. Resiko terjadinya kecelakaan kerja pada karyawan pemanenan TBS selain disebabkan oleh metode kerja pemanenan TBS yang tidak benar dan aman, diperparah pula dengan rendahnya kesadaran karyawan akan kesehatan dan keselamatan kerja seperti tidak memakai alat pelindung diri (APD) seperti sepatu boot, helm, kacamata dan apron, tidak fokus pada pekerjaan yang sedang dilakukan (melakukan pekerjaan memanen buah sawit sambil melakukan aktifitas lain seperti merokok, mengobrol, dan lain-lain), dan sikap abai terhadap keselamatan kerja lainya. 


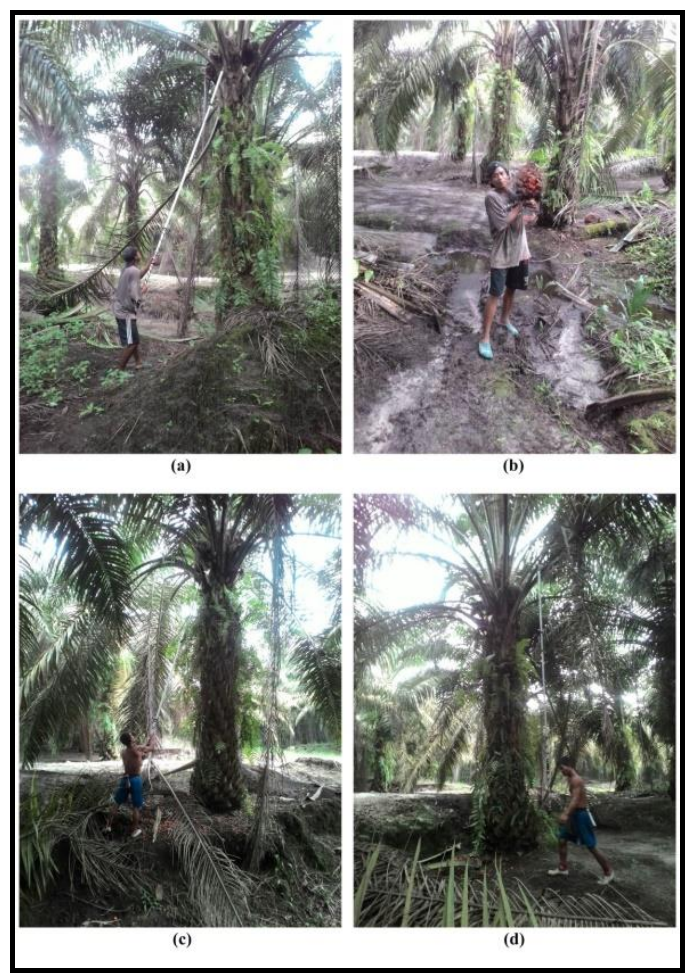

Gambar 1. Potensi Berbahaya Terjadinya Kecelakaan Kerja: (a) Mengegrek Buah Sawit (b) Mengangkat Buah Sawit (c) Memotong Pelepah Sawit (d) Memindahkan Pelepah Sawit

Agar kecelakaan kerja tidak berkelanjutan terjadi maka perlu dilakukannya berbagai upaya pengendalian kecelakkan kerja menggunakan metode analisa kecelakaan kerja yang efektif dan efisien. Salah satu metode anliasa kecelakaan kerja yang dapat digunakan adalah metode Event and Causal Factor Analysis (ECFA).

Tujuan penelitian ini adala untukm mengetahui penyebab kecelakaan kerja yang dialami karyawan pemanen TBS menggunakan metode Even and Causal Factor Analysis (ECFA) memberi usulan perbaikan sistem keselamatan dan kesehatan kerja kepada pemanenan TBS agar kecelakaan kerja yang saat ini masih terjadi dan dialami oleh karyawan dapat diminimalisir dan tidak terulang kembali.

\section{Landasan Teori}

Kesehatan dan Keselamatan Kerja

Filosofi Kesehatan dan Keselamatan Kerja (K3) merupakan pemikiran dan upaya untuk menjamin keutuhan dan kesempurnaan. Yang dijamin dalam filosofi tersebut adalah sebagai berikut:

1. Tenaga kerja dan manusia pada umumnya, baik jasmanai maupun rohani.

2. Hasil karya dan budaya menuju masyarakat adil, makmur, dan sejahtera.
Dalam Undang-Undang Dasar 1945 mengisyaratkan kesehatan dan keselamatan bagi tenaga kerja dan segala resiko yang ditimbulkan dari kecelakaan kerja baik kematian, cacat, cidera, penyakit dan lain-lain adalah dijamin dengan dasar kemanusian [1].

Kesehatan dan Keselamatan Kerja merupakan unsur penting agar kita dapat menikmati hidup yang berkualitas, baik di rumah maupun dalam pekerjaan. Kesehatan dan Keselamatan Kerja juga juga menjadi faktor penting dalam menjaga kelangsungan hidup suatu organisasi (perusahaan). Fakta ini ini dinyatakan oleh Health and Safety Executive (HSE) atau pelaksaan kesehatan dan keselamatan kerja sebagai 'Good Health Business' (kesehatan yang baik menunjang bisnis yang baik) [2].

Secara hakiki Kesehatan dan Keselamatan Kerja, merupakan upaya atau pemikiran serta penerapan yang ditujukan untuk menjamin keutuhan dan kesempurnaan baik jasmaniah maupun rohaniah tenaga kerja khususnya dan manusia pada umumnya, hasil karya dan budaya, untuk meningkatkan kesejahteraan tenaga kerja [3].

Keselamatan dan Kesehatan Kerja bertalian erat dengan mesin, pesawat, alat kerja, bahan-bahan, dan proses pengolahannya, landasan tempat kerja dan lingkungannya serta cara-cara melakukan pekerjaan. Kesehatan dan Keselamatan Kerja bersasaran ke segala tempat kerja, baik di darat, di dalam tanah, di permukaan air, maupun di udara. Kesehatan dan Keselamatan Kerja menyangkut segenap proses produksi dan distribusi, baik barang maupun jasa, serta seganap kegiatan perekonomian, seperti pertanian, industri, pertambangan, perhubungan, pekerjaan umum, dan lain lain. Kesehatan dan Keselamatan Kerja adalah tugas semua orang yang berkerja. Kesehatan dan Keselamatan Kerja adalah dari, oleh, dan untuk setiap tenaga kerja serta orang lainnya, dan juga masyarakat pada umumnya [1].

Berdasarkan pengertian umum, Kesehatan dan Keselamatan Kerja (K3) telah banyak diketahui sebagai salah satu persyaratan dalam melaksanakan tugas, dan suatu bentuk faktor hak asasi manusia. Perhatian inti terhadap K3 mencakup hal-hal berikut ini [3]: Penerapan prinsip-prinsip sains (application of scientific principles).

1. Pemahaman pola resiko (understanding the nature of risk).

2. Ruang lingkup ilmu K3 cukup luas baik di dalam maupun di luar industri.

3. K3 merupakan multidisiplin profesi.

4. Ilmu-ilmu dasar yang terlibat dalam keilmuan K3 adalah fisik, kimia, biologi, dan ilmu-ilmu prilaku.

5. Area garapan: industri, transportasi, penyimpanan dan pengolahan material, domestik, dan kegiatan lainnya seperti rekreasi. 
Dipandang dari aspek keilmuan, K3 merupakan suatu ilmu pengetahuan dan penerapannya dalam upaya mencagah kecelakaan, kebakaran, peledakan, pencemaran, dan penyakit akibat kerja. Terdapat dua aspek utama yang menjadi fokus utama dalam $\mathrm{K} 3$, yaitu [3]):

1. Kesehatan Kerja (Health), adalah suatu keadaan seorang pekerja yang terbebass dari gangguan fisik dan mental sebagai akibat pengaruh interaksi pekerjaan dan lingkungan.

2. Keselamatan Kerja (Safety), adalah suatu keadaan yang aman dan selamat dari penderitaan dan kerusakan serta kerugian di tempat kerja, baik pada saat memakai alat, bahan, mesin-mesin dalam proses pengolahan, teknik pengepakan, penyimpanan, maupun menjaga dan mengamankan tempat serta lingkungan kerja.

Secara umum keselamatan kerja memiliki makna sebagai berikut [3]:

1. Pengendalian kerugian dari kecelakaan (control of accident loss).

2. Kemampuan untuk mengidentifikasi, mengurangi dan mengendalikan resiko yang tidak bisa diterima (the ability to identify and eliminate unacceptable risk).

Kesehatan dan Keselamatan Kerja (K3) adalah sarana untuk pencegahan kecelakaan, cacat dan kematian sebagai akibat kecelakaan kerja. K3 yang baik adalah pintu gerbang bagi keamanan tenaga kerja. Secara umum K3 memiki tujuan sebagai berikut [1]:

1. Melindungi tenaga kerja atas hak keselamatannya dalam melakukan pekerjaan untuk kesejahteraan hidup dan meningkatkan produksi serta produktivitas nasional.

2. Menjamin keselamatan setiap orang lain yang berada di tempat kerja.

3. Sumber produksi dipelihara dan dipergunakan sercara aman dan efisien.

Berbagai tujuan dari penerapan Keselamatan dan Kesehatan Kerja (K3) adalah sebagai berikut [4]:

1. Meningkatkan efektifitas perlindungan kesehatan dan keselamatan kerja yang terencana, terukur, terstruktur, dan terintegrasi.

2. Mencegah dan mengurangi kecelakaan kerja dan penyakit akibat kerja dengan melibatkan unsur manajemen, pekerja/buruh, dan/atau serikat pekerja/serikat buruh.

3. Serta menciptakan tempat kerja yang aman, nyaman, dan efisien untuk mendorong produktivitas.

\section{Kecelakaan Kerja}

Seiring dengan berkembangnya dunia industri, dunia kerja selalu dihadapkan pada tantangantantangan baru yang harus bisa segera diatasi bila perusahaan tersebut ingin tetap eksis. Berbagai macam tantangan baru muncul seiring dengan perkembangan jaman. Namun masalah yang selalu berkaitan dan melekat dengan dunia kerja sejak awal dunia industri dimulai adalah timbulnya kecelakaan kerja.

Kecelakaan kerja adalah suatu kejadian yang tak terduga dan yang tidak diharapkan. Tak terduga oleh karena di belakang peristiwa itu tidak terdapat unsur kesengajaan, lebih-lebih dalam bentuk perencanaan. Maka dari itu, peristiwa sabotase atau tindakan kriminal di luar ruang lingkup kecelakaan yang sebenarnya tidak diharapkan, oleh kerena peristiwa kecelakaan disertai kerugian material ataupun penderitaan dari yang paling ringan sampai kepada yang paling berat [1].

Kecelakaan kerja merupakan sebuah kejadian takterduga yang menyebabkan cedera atau kerusakan. Suatu kecelakaan bukanlah suatu peristiwa tunggal, melainkan kecelakaan ini merupakan hasil dari serangkaian penyebab yang saling berkaitan [5].

Kecelakaan akibat kerja adalah kecelakaan berhubungan dengan hubungan kerja pada perusaaan. Hubungan kerja di sini dapat berarti, bahwa kecelakaan terjadi dikarenakan oleh pekerjaan atau pada waktu melaksanakan pekerjaan. Maka dalam hal ini terdapat dua permasalahan penting, yaitu [1]:

1. Kecelakaan akibat langsung dari suatu pekerjaan.

2. Kecelakaan yang terjadi saat pekerjaan sedang dilakukan.

Kecelakaan kerja menurut Peraturan Menteri Tenaga Kerja No. 3 adalah suatu kejadian yang tidak dikehendaki dan tidak diduga semula yang dapat menimbulkan korban manusia dan/atau harta benda [5].

Kecelakaan kerja adalah suatu kejadian yang jelas tidak dikehendaki dan sering kali tidak terduga semula yang dapat menimbulkan kerugian baik waktu, harta benda atau properti maupun korban jiwa yang terjadi didalam suatu proses kerja industri atau yang berkaitan denganya [6].

Berdasarkan beberapa pengertian kecelakaan kerja menurut berbagi sumber dapat disimpulkan bahwa kecelakaan akibat kerja adalah suatu peristiwa yang tidak terduga, tidak terencana tidak dikehendaki dan menimbulkan kerugian baik jiwa maupun harta yang disebabkan oleh pekerjaan atau pada waktu melaksanakan pekerjaan yaitu ketika pulang dan pergi ke tempat kerja melalui rute yang biasa dilewati.

Dengan demikian kecelakaan kerja mengandung unsur sebagai berikut [6]:

1. Tidak diduga semula, oleh karena dibelakang peristiwa kecelakaan tidak terdapat unsur kesengajaan dan perencanaan. 
2. Tidak diinginkan atau diharapkan karena setiap peristiwa kecelakaan akan selalu disertai kerugian baik fisik maupun mental.

3. Selalu menimbulkan kerugian dan kerusakan, yang sekurang-kurangnya menyebabkan gangguan proses kerja.

Kecelakaan kerja dapat disebabkan oleh beberapa faktor faktor manusia, faktor peralatan kerja, dan faktor dari lingkungan kerja [7].

Kecelakaan kerja berhubungan dengan hubungan kerja di perusahaan.Hubungan kerja dalam hal ini adalah kecelakaan kerja yang terjadi disebabkan oleh karyawan itu atau kesalahan dalam peralatan yang digunakan oleh karyawan pada waktu melaksanakan pekerjaan [8].

Dalam PP II/ 1979 kecelakaan dibagi kedalam 3 jenis yang ditentukan sesuai dengan kebutuhan yaitu, Kecelakaan Ringan, Sedang dan Berat:

1. Kecelakaan Ringan: Kecelakaan atau keracunan setelah mendapatkan pertolongan pertama hanya mendapat istirahat dokter maximum 2 hari.

2. Kecelakaan Sedang: Kecelakaan atau keracunan setelah mendapatkan pertolongan mangakibatkan harus istirahat lebih dari 3 hari dan tidak mengakibatkan cedera.

3. Kecelakaan Berat: Kecelakaan atau keracunan setelah mendapatkan pertolongan pertama mangakibatkan harus istirahat lebih dari 3 serta mengakibatkan cedera.

Perbaikan sistem manajemen Kesehatan dan keselamatan kerja (SMK3) dapat dilakukan dengan cara sebagai berikut: Perusahaan harus lebih mengawasi kepada para pekerja yang melanggar peraturan keselamatan kerja dalam penggunaan APD dan selalu memperingatkan pekerja untuk lebih berhati - hati selama bekerja.Perusahaan dapat memperhatikan penerapan K3 yang baik bagi pekerjaan agar tidak terjadi hal - hal yang dapat menimbulkan risiko yang sangat tinggi.Perusahaan dapat melakukan pemeriksaan yang rutin terhadap pekerja, alat dan berbagai hal yang menyangkut Kesehatan dan Keselamatan Kerja (K3).Pekerja dapat mengikuti setiap intruksi ataupun aturan yang diterapkan oleh pihak managemen secara berkesinambungan sehingga target zero accident dapat tercapai [9].

\section{Metodologi Penelitian}

Pada penelitian ini menggunakan metode Event and Causal Factor Analysis (ECFA).

Event and Causal Factor Analysis (ECFA) merupakan aplikasi dari metode analisa kecelakaan untuk menentukan faktor penyebab dengan mengidentifikasi kejadian-kejadian dan kondisi-kondisi yang signifikan yang dapat menyebabkan terjadinya suatu kecelakaan. Dalam penerapan metode ECFA akan didapatkan hasil akhir berupa Event and Causal Factor Analysis Diagram, dimana diagram ini menggambarkan suatu rangkaian logis dari kejadian dan kondisi-kondisi terkait yang mendahului suatu kecelakaan (Buys dan Clark, 1995).

ECFA memiliki tiga tujuan utama dalam menginvestigasi, yaitu:

1. Membantu memverifikasi rantai kausal dan urutan event (kejadian).

2. Menyediakan struktur untuk mengintegrasikan temuan investigasi kecelakaan.

3. Membantu mengkomuniksikan baik selama proses penyelidikan dan pada penyelesaian penyelidikan kecelakaan.

Adapun faktor penyebab kecelakaan kerja biasanya disebabkan oleh karyawan tidak memakai APD, karyawan tidak fokus saat bekerja, karyawan lengah dan lalai, kurang penataan ruangan, alat yang berserakan, tidak konsentrasi, serta kurangnya pengetahuan dan pemahaman tentang K3 [10].

Melakukan pengawasan terhadap para karyawan sehingga karyawan tidak lagi bekerja sesuai keinginannya tetapi sesuai dengan standard yang ditetapkan selain itu pelatihan tentang K3 juga perlu dilakukan terutama yang berhubungan dengan penggunaan APD sehingga pekerja menjadi lebih aman dalam bekerja.Sebaiknya jadwal pelatihan K3 tentang penggunaan APD yang akan diselenggarakan oleh pihak manajemen secara rutin [11].

Penerapan prosedur dan peraturan di tempat kerja, serta pengendalian lingkungan kerja.Keselamatan dan kesehatan kerja mempunyai peranan penting dalam perusahaan, karena dampak kecelakaan dan penyakit yang diakibatkan karena kurangnya kepedulian keselamatan dan kesehatan kerja tidak hanya merugikan tenaga kerja, tetapi juga merugikan perusahaan [12]

\section{Hasil dan Pembahasan}

Investigasi kecelakaan kerja ECFA dilakukan untuk mengetahui penyebab dari kejadian dan menentukan tindakan yang dapat diambil untuk mencegah kejadian terssebut terulang kembali dimasa mendatang. Identifikasi penyebab utama ini dilakukan dengan cara mengamati dan memepelajari hubungan antara kejadian dan faktor penyebab atau kondisi secara terstruktur.

1. Tertimpa Pelepah atau Janjangan Buah Sawit.

a. Kronologi Kejadian

Tertimpa pelepah atau janjangan buah sawit karena jatuhnya pelepah atau janjangan buah sawit yang telah dipotong dengan egrek dari ketinggian.

b. Kerugian yang Ditimbulkan Luka memar, luka robek, terkilir, patah tulang, kematian, dan cidera lain sebagainya. 


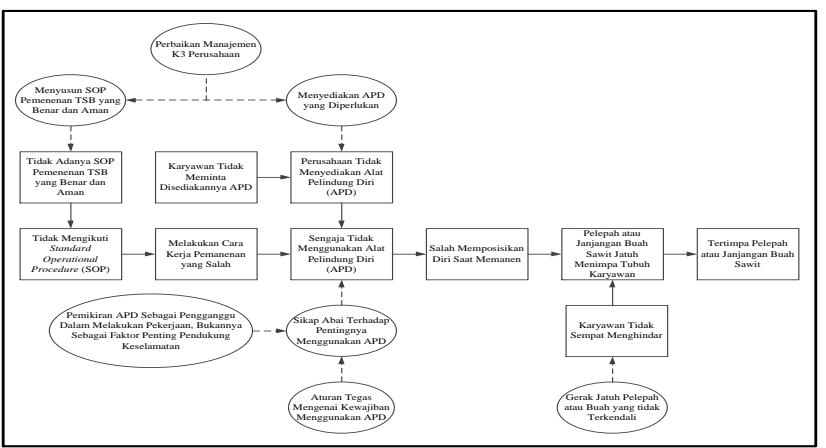

Gambar 2. ECFA Chart Kecelakaan Kerja Tertimpa Pelepah atau Janjangan Buah Sawit

c. Analisa ECFA

- Direct Cause: gerak jatuh pelepah atau janjangan buah sawit dari ketinggian pohon sawit yang tidak terkendali

- Root Cause: manajemen K3 perusahaan yang tidak memiliki SOP kerja memanen TBS yang benar dan aman, dan juga tidak menyediakan dan mendisribusikan kepada karyawan APD yang tepat untuk pekerjaan pemanenan TBS dan adanya anggapan karyawan bahwa menggunakan APD justru menjadi pengganggu atau penghambat dalam melakukan pekerjaan.

- Contributing Cause: tidak adanya aturan yang tegas yang mewajibkan karyawan menggunakan APD dan juga berkerja harus sesuai SOP yang benar dan aman.

2. Kejatuhan Berondolan Sawit, Serbuk Bunga Sawit atau Sampah Lainnya.

a. Kronologi Kejadian

Pada saat mengekrek pelepah atau janjangan buah sawit berondolan sawit, serbuk-serbuk bunga sawit atau sampah-sampah lainya turut terjatuh mengenai wajah khususnya pada bagian mata karyawan, sedangkan karyawan dalan keadaan tidak mengenakan pelindung kepala (helmet) dan pelindung mata (kacamata).

b. Kerugian yang Ditimbulkan

Luka memar, iritasi mata, luka pada mata, cacat pada mata, kebutaan, dan cidera lain-lainnya.

c. Diagram ECF

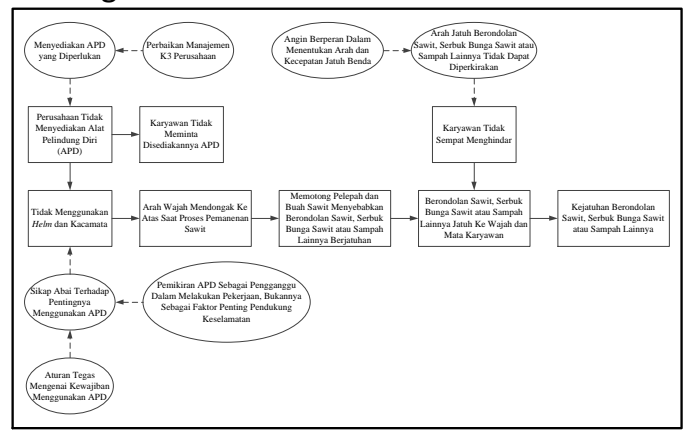

Gambar 3. ECFA Chart Kejatuhan Berondolan Sawit, Serbuk Bunga Sawit atau Sampah Lainnya

\section{d. Analisa ECFA}

- Direct Cause: yaitu jatuhnya berondolan sawit, serbuk bunga sawit, atau sampah lainnya mengenai bagian kepala dan wajah, terutama pada bagian mata karyawan dikarenakan arah jatuh berondolan sawit, serbuk bunga sawit, atau sampah lainnya tidak dapat diperkirakan.

- Root Cause: tidak disediakannya peralatanperalatan perlindungan diri atau APD oleh manajemen K3 peruasahan guna meminimalkan resiko yang ditimbulkan jika kecelakaan kerja kejatuhan berondolan sawit, serbuk bunga sawit, atau sampah lainnya terjadi menimpa karyawan.

- Contributing Cause: ketidak tegasan manajemen K3 perusahaan dalam mewajibkan karyawan menggunakan APD pada saat berkerja, faktor lingkungan seperti misalnya angin yang menyebabkan arah jatuh serbuk bungan sawit dan sampah lainya menjadi sulit diperhitungkan.

3. Tertusuk Duri Sawit.

a. Kronologi Kejadian

Kurangnya kehati-hatian dalam memindahkan dan mengangkut pelepah atau janjangan buah sawit serta tidak lengkapnya APD yang digunakan seperti sarung tangan kerja, pakaian kerja yang menutupi seluruh bagian tubuh dan juga sepatu boot.

b. Kerugian yang Ditimbulkan

Luka tusuk, timbulnya rasa nyeri, dan sebagainya.

\section{c. Diagram ECF}

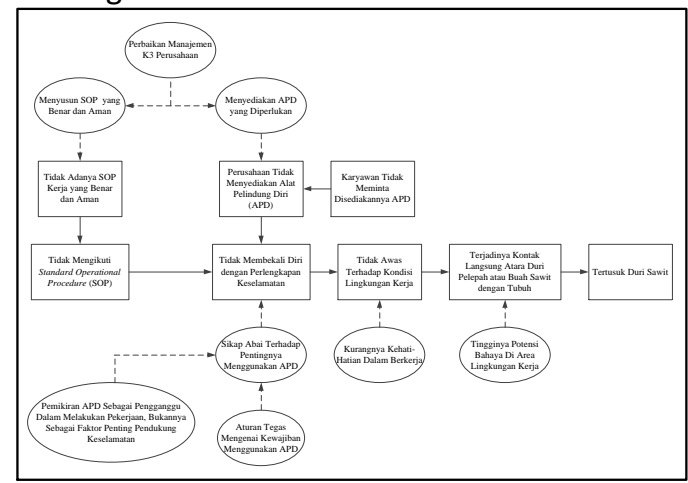

Gambar 4. ECFA Chart Tertusuk Duri Sawit

\section{d. Analisa ECFA}

- Direct Cause: tingginya potensi bahaya di area lingkungan kerja serta kekurangnya hatihatian karyawan saat berkerja menjadi penyebab seringnya terjadi kontak atara karyawan dengan sumber bahaya dalam hal ini duri pelepah maupun duri janjangan buah sawit.

- Root Cause: rendahnya peranan manajeman K3 perusahaan dalam menyediakan APD dan 
SOP kerja memanen TBS yang benar dan aman

- Contributing Cause: tidak adanya aturan yang tegas yang mengaharuskan karyawan menggunakan APD pada saat melakukan pekerjaan dan juga berkerja harus mengukuti SOP yang benar dan aman.

4. Tersandung, Terpeleset, atau Terjatuh.

a. Kronologi Kejadian

Umumnya kecelakaan kerja jenis ini berkaitan dengan kondisi lingkungan kerja, misalnya seperti jalan yang licin, kontur permukaan tanah yang tidak rata, banyaknya tumbuhan-tumbuhan yang dapat menyebabkan tersandung, dan penyebab lain sebagainya, resiko dari terjadinya kecelakaan kerja ini semakin diperparah karena pada saat kecelakaan kerja itu terjadi karyawan dalam keadaan membawa beban yang berat atau alat-alat kerja yang tajam serta minimnya APD yang digunakan.

b. Kerugian yang Ditimbulkan

Luka memar, luka gores, keseleo, terkilir, dan cidera lainnya.

c. Diagram ECF

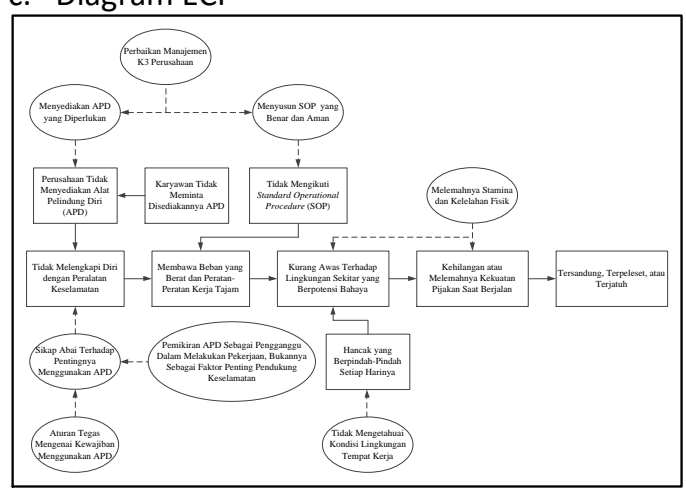

Gambar 5. ECFA Chart Tersandung, Terpeleset, atau Terjatuh

d. Analisa ECFA

- Direct Cause: melemahnya stamina dan kelehan fisik yang diderita karyawan akibat beratnya beban kerja memanen tandan buah sawit (TBS), dan juga kurangnya pengetahun karyawan mengenai kondisi lingkungan tempat kerjanya.

- Root Cause: belum sempurnanya peranan manajeman K3 perusahaan dalam menyediakan APD dan SOP kerja memanen TBS yang benar serta aman dan juga pemahaman karyawan yang menganggap dengan mereka menggunakan APD saat melakukan pekerjaan akan mengganggu dan menghambat pekerjaan.

- Contributing Cause: tidak adanya aturan yang tegas yang mengaharuskan karyawan menggunakan APD pada saat melakukan pekerjaan dan juga SOP yang benar dan aman.
5. Terluka Atau Cidera Karena Alat Kerja.

a. Kronologi Kejadian

Kecelakaan kerja ini disebabkan oleh peralatanperalatan kerja yang tajam seperti egrek, kampak, dan gancu umunya dikarenakan kelalaian dan kurangnya kehari-hatian dari karyawan dalam memposisikan dan menempatkan peralatan-peralatan kerja tersebut.

b. Kerugian yang Ditimbulkan

Luka robek, luka sayatan, anggota tubuh terputus, dan cidera-cidera lainnya.

c. Diagram ECF

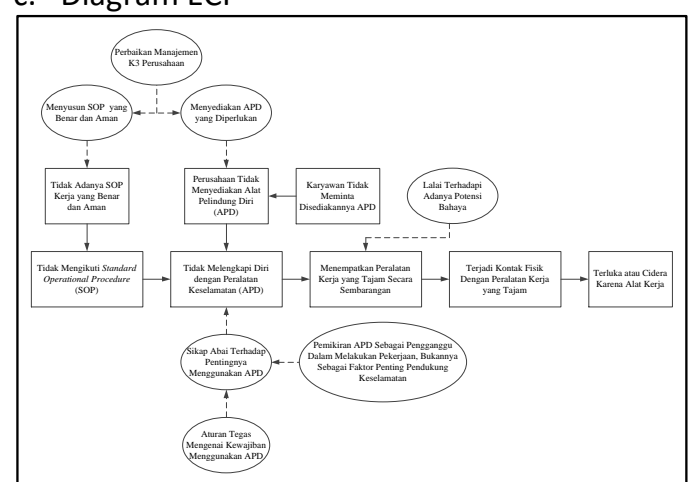

Gambar 6. ECFA Chart Terluka atau Cidera Karena Alat Kerja

d. Analisa ECFA

- Direct Cause: keryawan yang melalaikan adanya potensi berbahaya yang ditimbulkan dari peralatan kerja tajam yang diletakkan secara sembarangan, padahal mereka menyadari hal tersebut.

- Root Cause: peranan manajemen K3 perusahaan yang tidak menyediakan SOP kerja memanen TBS yang benar dan aman.

- Contributing Cause: tidak tegasnya penerapan aturan yang mewajibkan karyawan menggunakan APD saat berkerja dan juga berkerja harus sesuai SOP yang benar dan aman.

Rekomendasi yang diberikan sebagai hasil dari penganalisaan investigasi kecelakaan kerja menggunakan metode ECFA dalam upaya meminimalisir dan pencegahan kecelakaan kerja terulang dimasa mendatang berupa, perlu adanya perbaikan dari internal manajemen K3 perusahaan dalam hal ketersedian peralatan-peralatan keselamatan atau APD sesuai dengan yang dibutuhkan, serta harus segera disusun Standard Operational Procedure (SOP) kerja pemanenan TBS yang benar dan aman. Selain itu pula perlu adanya upaya yang serius dari perusahaan guna menanamkan pada diri karyawan bahwa keselamatan dirinya dalam berkerja merupakan yang utama dan mengenakan APD pada saat berkerja merupakan suatu keharusan. 


\section{Kesimpulan}

Bedasarkan pembahasan penelitian yang telah dilakukan terhadap terjadinya kecelakaan kerja pemaenan tandan buah sawit (TBS) di PT. XYZ disimpulkan beberapa hal yaitu sebagai berikut:

1. Faktor penyebab terjadinya kecelakan kerja menggunakan metode ECFA dapat disimpulkan bahwa kecelakaan kerja yang terjadi disebabkan oleh:

a. Penyebab Langsung

Terjadinya kecelakaan kerja pada karyawan panen TBS secara langsung disebabkan karena tidak adanya metode atau standar kerja yang baku, tidak memakai APD saat berkerja, kondisi lingkungan kerja yang berada dilur ruangan (kebun) dengan berbagai potensi bahaya yang ada, dan sikap abai terhadap keselamatan kerja melalui prilaku karyawan yang tidak fokus pada pekerjaan yang sedang dilakukannya.

b. Penyebab Dasar

Faktor yang mendasari terjadinya kecelakaan kerja pada karyawan panen karena kurangnya pengetahuan karyawan akan pentingnya keselamatan dan kesehatan mereka dalam berkerja, ketidaktahuan tentang tata cara kerja yang baik dan aman karena tidak adanya SOP kerja yang benar dan aman, beban pekerjaan yang berat terjadinya kelehan fisik dan psikologis, kurangnya rekayasa dan simulasi kesehatan dan keselamatan diri, kurangnya perencanaan dan pengadaaan APD dari pihak perusahaan, kurang atau tidak ada pengawasan dari pimpinan perusahaan guna memastikan karyawannya berkerja dengan benar dan aman serta didukung APD yang memadai, dan program K3 yang tidak sesuai atau bahkan tidak ada.

2. Usulan perbaikan sistem keselamatan dan kesehatan kerja (K3) melalui pembuatan Standard Operational Procedure (SOP) keselamatan kerja pemanenan TBS, peningkatan kesedaran diri karyawan terhadap pentingnya keselamatan kerja, merencanakan pengadaan perlengkapan APD sesuai yang dibutuhkan, mewajibkan penggunaan APD oleh setiap karyawan pada saat berkerja, melakukan pengawasan terhadap kesehatan dan keselamatan kerja karyawan, membuat dan menjalankan program kesehatan dan keselamatan kerja.

\section{Daftar Pustaka}

[1] Suma'mur, P.K. “Keselamatan Kerja Dan Pencegahan Kecelakaan". Haji Masagung, Jakarta. 1989.

[2] Ridley, John. "Kesehatan Dan Keselamatan Kerja". Penerbit Erlangga. Jakarta. 2008.
[3] Kuswana, Wowo Sunaryo. "Ergonomi dan K3 (Kesehatan Dan Keselamatan Kerja)". PT. Remaja Rosdakarya, Bandung. 2014.

[4] Ramli, Soehatman. "Sistem Manajemen Keselamatan Dan Kesehatan Kerja OHSAS 18001". Dian Rakyat, Jakarta. 2010.

[5] Dainur. "Materi-materi Pokok Ilmu Kesehatan Masyarakat". Widya Medika. Jakarta. 1992.

[6] Tarwaka. "Keselamatan Dan Kesehatan Kerja". Harapan Press, Surakarta. 2008.

[7] Nur, Muhammad dan Chania, D., O. 2016.Pengaruh Pelaksanaan Program Keselamatan dan Kesehatan Kerja (K3) terhadap Produktivitas Kerja Karyawan pada PT. Bormindo Nusantara Duri. UIN Sultan Syarif Kasim Riau. [Online] Availablehttp://ejournal.uinsuska.ac.id/index.php/jti/article/view/5576, diakses 13 September 2020.

[8] Nur, Muhammad dan Al, Anshari. 2015. Analisis Keselamatan Dan Kesehatan Kerja Terhadap Kinerja Karyawan PT. Johan Sentosa (PKSBangkinang). UIN Sultan Syarif Kasim Riau. [Online] Availablehttp://ejournal.uinsuska.ac.id/index.php/jti/article/view/6320, diakses 13 September 2020.

[9] Nur, Muhammad dan Afriani Putri. 2019. Usulan Perbaikan Sistem Manajemen Keselamatan dan Kesehatan Kerja (SMK3) sebagai Upaya Meminimalisir Angka Kecelakaan Kerja Mengguna kan Metode HAZOP (Studi Kasus: PT. $X Y Z$ ).Institut Teknologi Kalimantan [Online] Available

https://journal.itk.ac.id/index.php/sjt/article/vie w/152/74 diakses 13 September 2020.

[10] Nur, Muhammad dan Suryandri Halbi. 2019. Analisa Lingkungan Kerja dan Kesehatan, Keselamatan Kerja (K3) pada Studi Kasus di PT. Asrindo Citraseni Satria. Institut Teknologi Kalimantan [Online]. Available https://journal.itk.ac.id/index.php/sjt/article/vie w/151/71 diakses 13 September 2020.

[11] Nur, Muhammad. 2018. Analisis Keselamatan dan Kesehatan Kerja Menggunakan Metode Hazard And Operability Study (HAZOP) Di PT. XYZ. UIN Sultan Syarif Kasim Riau. [Online] Available http://ejournal.uin-

suska.ac.id/index.php/jti/article/view/6627/4663 diakses 13 September 2020

[12] Nur, Muhammad dan Oki Ariwibowo. 2018. Analisis Kecelakaan Kerja dengan Menggunakan Metode FTA Dan 5s di PT. Jingga Perkasa Printing. UIN Sultan Syarif Kasim Riau. [Online] Available http://ejournal.uinsuska.ac.id/index.php/iti/article/view/6038 diakses 13 September 2020. 